\title{
Copper Adsorption as a Function of Solution Parameters of Variable Charge Soils
}

\author{
Ernesto R. Mouta, Marcio R. Soares* and José C. Casagrande \\ Centro de Ciências Agrárias, Departamento de Recursos Naturais e Proteção Ambiental, \\ Universidade Federal de São Carlos, Rodovia Anhangüera, km 174, \\ CP 153, 13600-970 Araras-SP, Brazil
}

\begin{abstract}
Os efeitos do $\mathrm{pH}$ e da força iônica (I) sobre a adsorção de cobre $(\mathrm{Cu})$ e a força direcional da reação em solos com cargas variáveis foram avaliados a partir de experimentos tipo "batch". Os resultados foram ajustados pelo modelo de Langmuir e, de acordo com as isotermas de adsorção, a afinidade de $\mathrm{Cu}\left(\mathrm{K}_{\mathrm{L}}\right)$ foi maior nas amostras do subsolo $\left(0,061-0,468 \mathrm{~L} \mathrm{~kg}^{-1}\right)$ do que na camada superficial $\left(0,169-0,359 \mathrm{~L} \mathrm{~kg}^{-1}\right)$. A adsorção máxima variou de $1114-2422 \mathrm{mg} \mathrm{kg}^{-1}$ (superfície) a 1002-1334 mg kg-1 (subsolo). Foi observada forte dependência da adsorção de $\mathrm{Cu}$ em relação ao pH nas amostras do subsolo, com nítido aumento da retenção de $\mathrm{Cu}$ (20-90\%) no intervalo de $\mathrm{pH}$ do solo entre 4,0-5,0. A adsorção de $\mathrm{Cu}$ foi alterada pelo aumento da I e indicou diferentes mecanismos (esferas interna e externa) de retenção do metal. A reação foi favorável e espontânea, conforme indicado pelos valores negativos da variação da energia livre $(\Delta G)$ e pelo fator de separação $K_{R}$ $<1$. A interface solo-solução e a adsorção de $\mathrm{Cu}$ foram termodinamicamente descritas por uma abordagem teórica.
\end{abstract}

Effects of $\mathrm{pH}$ and ionic strength (I) on copper $(\mathrm{Cu})$ adsorption and the driving force of the reaction in variable charge soils were evaluated from batch studies. Experimental results of $\mathrm{Cu}$ adsorption fitted Langmuir model. According to adsorption isotherms, $\mathrm{Cu}$ affinity $\left(\mathrm{K}_{\mathrm{L}}\right)$ was greater in the subsoil $\left(0.061-0.468 \mathrm{~L} \mathrm{~kg}^{-1}\right)$ than in the topsoil samples $\left(0.169-0.359 \mathrm{~L} \mathrm{~kg}^{-1}\right)$. Maximum adsorption (Ads $_{\max }$ ) ranged from 1114-2422 $\mathrm{mg} \mathrm{kg}^{-1}$ (topsoil) to $1002-1334 \mathrm{mg} \mathrm{kg}^{-1}$ (subsoil). Strong dependence of $\mathrm{Cu}$ adsorption on the $\mathrm{pH}$ was observed in subsoil samples. Adsorption edges showed sharply increase of $\mathrm{Cu}$ adsorption (20-90\%) in the 4.0-5.0 pH range. Copper adsorption changed with increase in I and indicated different metal retention mechanisms (outer- and inner-spheres). Adsorption reaction was favorable and spontaneous, as indicated by negative values of the free energy variation $(\Delta G)$ and the separation factor $K_{R}<1$. Soil-solution interface and Cu adsorption were also thermodynamically described by a theoretical approach.

Keywords: tropical soils, ionic strength, $\mathrm{pH}$, isotherms, Langmuir

\section{Introduction}

Copper $(\mathrm{Cu})$ is an internal transition metal found naturally in the soil in concentrations that vary from 2 to $100 \mathrm{mg} \mathrm{kg}^{-1}$. These contents correspond to the lithogenous fraction that, when released from the crystalline structures in the rocks by weathering processes, become part of the natural biogeochemical cycle. ${ }^{1}$ Anthropogenic sources have acted on the redistribution and increase in the metal transfer rates among the various compartments of ecosystems. Because it is an excellent heat and electricity conductor, $\mathrm{Cu}$ has been used on a large-scale by modern industrialized society as the main element of several metal alloys, such as bronze and brass. Copper has also been used in pigments, catalyzers, solvents

\footnotetext{
*e-mail: mrsoares@cca.ufscar.br
}

and various agricultural products, which include fertilizers, pesticides and some growth promoters in animal feed. ${ }^{2}$ Copper is a micronutrient that participates in bioecological cycles and meets the criteria of being essential to the full development of live beings. In plants, $\mathrm{Cu}$ acts as a structural element in proteins, participates in electron transport during photosynthesis, in the cell wall metabolism and as a cofactor of various enzymes. ${ }^{3}$ In higher animals, lack of $\mathrm{Cu}$ can cause bone dysfunctions, anemia and heart and gastrointestinal disturbances, while lung fibrosis and liver cancer are some of the chronic effects of overexposure to $\mathrm{Cu}^{2}$

The improper disposal of urban and industrial wastes derived from the processing and recycling of $\mathrm{Cu}$ and its by-products have created an increase in the quantity of $\mathrm{Cu}$ released in the soil. Under these conditions, $\mathrm{Cu}$ assumes a toxic characteristic because its admission to the food chain 
has been facilitated. Its mobility and bioavailability in the soil depend on the increase of its concentration in the soil solution, from where the metal can be absorbed by plants or translocated through leaching to the underground water sheets. Its persistence or its mobility in soil involve sorption, desorption, precipitation, complexation, oxy-reduction and dissolution reactions. ${ }^{4}$ Although all these reactions may occur simultaneously, adsorption mechanisms are known to be determinant in the control of metal availability and solubility in the soil. ${ }^{5}$

Interest in the adsorption phenomena of metal ions by surfaces with $\mathrm{pH}$ dependent charges has increased recently, as an effort to increase understanding of the dynamic of these contaminants in tropical environments. In the case of $\mathrm{Cu}$, the agronomic interest concerns its availability, while regarding the environmental and public health aspects, its retention in the soil is desirable. In soils with reversible interfaces, adsorption changes in response to variations of solution parameters, such as the $\mathrm{pH}$ and ionic strength (I). ${ }^{6}$ In general, $\mathrm{pH}$ is the primary factor that governs heavy metal adsorption and availability, due to alterations in the metal species in solution and the variation in the intensity of deprotonation of the electrically charged surface. ${ }^{7-11}$ However, while solubility of some metal ions (e.g. Ni and $\mathrm{Cd}$ ) is strongly controlled by the $\mathrm{pH}, \mathrm{Cu}$ retention does not seem to depend on this parameter alone. ${ }^{9}$ Besides $\mathrm{pH}$, the organic matter is the most important factor that controls the performance of metal ions in soil. ${ }^{12}$ Organic complexes are particularly important in $\mathrm{Cu}$ retention by the soil under a wide variety of conditions, ${ }^{13-16}$ that influence the adsorption ${ }^{7}$ and desorption of the metal. ${ }^{17}$

Copper adsorption was studied in pure systems, such as $\mathrm{Fe}$ and $\mathrm{Al}$ (oxy)hydroxides (hematite and goethite) ${ }^{18-20}$ and clay minerals (kaolinite, illite etc), ${ }^{21-23}$ and in complex systems such as soil, under natural, agricultural or waste application conditions. ${ }^{7,24-26}$ Metal adsorption by soil (oxy) hydroxides has been identified as the main mechanism by which the metals are retained by the inorganic constituents of weathered soils. ${ }^{12,19,27}$ Even so, sufficient data has not yet been gathered on $\mathrm{Cu}$ adsorption by soils with variable charges in the wet tropics that would ensure the implementation of consistent techniques for prevention/ remediation of soil contamination.

Conceptual and quantitative models have been developed to prognosticate the fate and transport of metals in soil. Adsorption isotherms are more simplified approaches that describe the relationship between the adsorption concentrations and concentrations in solution and that supply quantitative parameters of the process, providing important data on the retention capacity and the metal affinity by the soil. ${ }^{28,29}$ Langmuir isotherm, fitted by non-linear models, was successfully applied in the study of metals in weathered soils, including $\mathrm{Cu}{ }^{24,30,31}$ However, the adsorption modeling in tropical soils is rarely accompanied by a more detailed description based on thermodynamics..$^{23,32-35}$ Some information on thermodynamic modeling was obtained for the adsorption reaction of some metal ions by homogeneous surfaces, such as the oxidic interfaces, ${ }^{20,36-38}$ but data on thermodynamics of the $\mathrm{Cu}$ adsorption reaction by soils are still limited. As the metal distribution between liquid and solid phases is a measure of the position of equilibrium in the adsorption process, the states of this system can be defined by a set of thermodynamic properties that can serve as measures of the extension and spontaneity of the adsorption reaction. ${ }^{39}$

The objectives of this study were to investigate the parameters of the $\mathrm{Cu}$ adsorption reaction by soils with a predominance of $\mathrm{Fe}$ and $\mathrm{Al}$ (oxy)hydroxides in their mineralogy and to assess the directional force of this reaction by studying thermodynamic parameters in function of the variation in the $\mathrm{pH}$ and the ionic strength.

\section{Experimental}

\section{Soils}

In order to study $\mathrm{Cu}$ adsorption, topsoil (0-0.2 m) and subsoil (greatest expression of the diagnostic B horizon) samples of two acric Oxisols [heavy clayey-textured Anionic "Rhodic" Acrudox (RA) and medium-textured Anionic "Xanthic" Acrudox (XA)] and of an Alfisol [heavy clayeytextured Rhodic Hapludalf (RH) $],{ }^{40}$ derived from basalt, were collected from locations in the State of São Paulo, Brazil (Ribeirão Preto - $21^{\circ} 10^{\prime} \mathrm{S}, 47^{\circ} 48^{\prime} \mathrm{W}$; Guaíra - 20¹9`S, $\left.48^{\circ} 18^{`} \mathrm{~W}\right)$.

\section{Soil characterization}

(Electro)chemical, physical and mineralogical characterization of soil samples was performed in fine air-dried soil samples, sieved through $2 \mathrm{~mm}$ mesh, according to well-established methods for soil analysis described in Camargo et al..$^{41}$ and Raij et al. ${ }^{42}$ Organic carbon (OC) contents were quantified by the classical Walkley-Black method, oxidizing the organic matter with $\mathrm{K}_{2} \mathrm{Cr}_{2} \mathrm{O}_{7}$ in the presence of $\mathrm{H}_{2} \mathrm{SO}_{4}$, followed by titration of excess $\mathrm{K}_{2} \mathrm{Cr}_{2} \mathrm{O}_{7}$ with $\mathrm{Fe}^{2+}$ ions obtained from a standardized ferrous ammonium sulfate solution. The $\mathrm{pH}$ was determined potentiometrically in both $\mathrm{H}_{2} \mathrm{O}$ and $1 \mathrm{~mol} \mathrm{~L}{ }^{-1} \mathrm{KCl}$ suspensions (1:2.5 soil:solution ratio) using a combined glass-calomel electrode. The difference $\Delta \mathrm{pH}=\mathrm{pH}_{\mathrm{KCl}}-\mathrm{pH}_{\mathrm{H} 2 \mathrm{O}}$ was used as an estimate of the 
Table 1. (Electro)chemical, physical and mineralogical attributes of the soils

\begin{tabular}{|c|c|c|c|c|c|c|c|c|c|c|c|c|c|c|c|c|c|c|c|}
\hline \multirow{4}{*}{$\begin{array}{c}\text { Depth } \\
\text { m }\end{array}$} & \multirow{4}{*}{$\mathrm{pH}_{\mathrm{H} 2 \mathrm{O}}$} & \multirow{4}{*}{$\Delta \mathrm{pH}$} & \multirow{4}{*}{ ZPSE } & \multirow{2}{*}{\multicolumn{3}{|c|}{ Charge density }} & \multirow{4}{*}{ ECEC } & \multirow{4}{*}{$\begin{array}{l}\text { SSA } \\
\mathrm{m}^{2} \mathrm{~g}^{-1} \\
\end{array}$} & \multirow{4}{*}{ Clay } & \multirow[b]{3}{*}{$\mathrm{OC}$} & \multirow[b]{3}{*}{$\mathrm{Kt}$} & \multirow[b]{3}{*}{$\mathrm{Gb}$} & \multicolumn{6}{|c|}{ Extract solution } & \multirow{4}{*}{$\mathrm{ki}$} \\
\hline & & & & & & & & & & & & & \multicolumn{2}{|c|}{$\mathrm{Na}-\mathrm{CBD}$} & \multicolumn{2}{|c|}{ Tamm } & \multicolumn{2}{|c|}{$\mathrm{H}_{2} \mathrm{SO}_{4}$} & \\
\hline & & & & $\sigma_{\mathrm{o}}$ & $\sigma_{\mathrm{H}}$ & $\sigma_{\mathrm{o}} / \sigma_{\mathrm{H}}$ & & & & & & & $\mathrm{Fe}_{\mathrm{d}}$ & $\mathrm{Al}_{\mathrm{d}}$ & $\mathrm{Fe}_{\mathrm{o}}$ & $\mathrm{Al}_{\mathrm{o}}$ & $\mathrm{Fe}_{\mathrm{sa}}$ & $\mathrm{Al}_{\mathrm{sa}}$ & \\
\hline & & & & \multicolumn{3}{|c|}{ 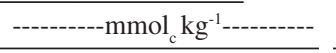 } & & & & 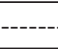 & 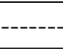 & 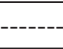 & 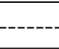 & $\mathrm{kg}^{-1}-$ & & - & $+\cdots$ & -1--- & \\
\hline \multicolumn{20}{|c|}{ Rhodic Hapludalf (RH) } \\
\hline $0.0-0.2$ & 5.7 & -0.9 & 3.6 & 63.1 & 30.2 & 2.1 & 108 & 134 & 820 & 26 & 249 & 59 & 150 & 23 & 12 & 8 & 270 & 167 & - \\
\hline $0.7-0.9$ & 6.0 & -0.7 & 3.6 & 35.4 & 30.9 & 1.2 & 54 & 151 & 700 & 7 & 263 & 80 & 150 & 21 & 14 & 7 & 284 & 195 & 0.90 \\
\hline \multicolumn{20}{|c|}{ Anionic "Rhodic" Acrudox (RA) } \\
\hline $0.0-0.2$ & 6.4 & -0.9 & 3.6 & 39.9 & 8.2 & 4.9 & 63 & 65 & 600 & 20 & 172 & 375 & 164 & 26 & 13 & 10 & 320 & 195 & - \\
\hline $1.0-1.4$ & 5.3 & +0.3 & 5.6 & 16.1 & 4.7 & 3.4 & 8 & 76 & 640 & 5 & 216 & 431 & 185 & 21 & 9 & 7 & 341 & 195 & 0.41 \\
\hline \multicolumn{20}{|c|}{ Anionic "Xanthic" Acrudox (XA) } \\
\hline $0.0-0.2$ & 4.6 & -0.6 & 3.4 & 32.3 & 8.4 & 3.8 & 13 & 65 & 350 & 16 & 248 & 200 & 39 & 22 & 2 & 6 & 66 & 91 & - \\
\hline $1.0-1.3$ & 5.1 & +0.6 & 6.0 & 18.4 & 1.3 & 14.2 & 3 & 53 & 450 & 6 & 196 & 189 & 43 & 31 & 2 & 8 & 96 & 125 & 0.65 \\
\hline
\end{tabular}

ZPSE = zero point of salt effect; $\sigma_{\mathrm{o}}=$ variable charge; $\sigma_{\mathrm{H}}=$ permanent charge; ECEC = effective cation exchange capacity; SSA = specific surface area; $\mathrm{OC}=$ organic carbon; $\mathrm{Kt}=$ Kaolinite; $\mathrm{Gb}=$ gibbsite; $\mathrm{Fe}_{\mathrm{d}}$ e $\mathrm{Al}_{\mathrm{d}}=$ iron and aluminum extracted by sodium citrate-bicarbonate-ditionite (Na-CBD); $\mathrm{Fe}_{\mathrm{o}}$ and $\mathrm{Al}_{\mathrm{o}}=$ iron and aluminum extracted by Tamm's solution $\left[(\mathrm{COOH})_{2} \mathrm{~s}_{2} \mathrm{O}+\left(\mathrm{NH}_{4}\right)_{2} \mathrm{C}_{2} \mathrm{O}_{4} \cdot \mathrm{H}_{2} \mathrm{O}\right] ; \mathrm{Fe}_{\text {as }}$ e $\mathrm{Al}_{\text {as }}=$ iron and aluminum extracted by $9 \mathrm{~mol} \mathrm{~L}^{-1} \mathrm{H}_{2} \mathrm{SO}_{4}$; $\mathrm{ki}=$ wheathering index $=\mathrm{SiO}_{2} / \mathrm{Al}_{2} \mathrm{O}_{3}$.

charge balance. ${ }^{43}$ Samples were investigated using the cesium $\left(\mathrm{Cs}^{+}\right)$adsorption method, which measures both structural permanent and variable charges and is based on the preference of $\mathrm{Cs}^{+}$over $\mathrm{Li}^{+}$in the siloxane surface sites and the lower selectivity of ionizable surface group for the $\mathrm{Cs}$ ion. ${ }^{44}$ Basic cations $(\mathrm{BC}=\mathrm{Ca}, \mathrm{Mg}, \mathrm{K}$ and $\mathrm{Na}$ ) were extracted by ion exchange resin. Calcium and $\mathrm{Mg}$ contents were determined by flame atomic absorption spectrophotometry and $\mathrm{Na}$ and $\mathrm{K}$ amounts were determined by flame atomic emission spectrophotometry. Exchangeable $\mathrm{Al}$ was extracted by $1 \mathrm{~mol} \mathrm{~L}^{-1} \mathrm{KCl}$ solution and determined by titration with $0.025 \mathrm{~mol} \mathrm{~L}^{-1}$ ammonium hydroxide. Effective cationic exchange capacity (ECEC) was estimated by the summation method (ECEC $=\mathrm{BC}+$ $\mathrm{Al}$ ). The $\mathrm{Fe}, \mathrm{Al}$ and $\mathrm{Si}$ contents, associated to the secondary minerals, were extracted using $9 \mathrm{~mol} \mathrm{~L}^{-1} \mathrm{H}_{2} \mathrm{SO}_{4}(1: 20$ soil/solution ratio). Levels of $\mathrm{Fe}$ and $\mathrm{Al}$ were determined using flame atomic absorption spectrophotometry and Si by gravimetry, and expressed in the form of oxides to calculate the weathering index by the molar ratio $\mathrm{ki}=\mathrm{SiO}_{2} / \mathrm{Al}_{2} \mathrm{O}_{3}$. Crystalline $\left(\mathrm{Fe}_{\mathrm{d}}\right)$ and poorly crystalline forms $\left(\mathrm{Fe}_{\mathrm{o}}\right)$ of $\mathrm{Fe}$ and $\mathrm{Al}$ oxides were extracted by sodium citrate-bicarbonate-dithionite (Na-CBD) and acid ammonium oxalate (Tamm's reagent) solutions, respectively. Zero point of salt effect (ZPSE) represented the $\mathrm{pH}$ value at the point of intersection of titration curves with $\mathrm{H}^{+}$and with $\mathrm{OH}^{-}$, at three $\mathrm{KCl}$ concentrations $(0.1 ; 0.01$ and $0.001 \mathrm{~mol}$ $\left.\mathrm{L}^{-1}\right){ }^{45}$ Particle analysis was performed by the pipette method, ${ }^{46}$ based on decantation speed of different soil particles after dispersion in $0.015 \mathrm{~mol} \mathrm{~L}^{-1}\left(\mathrm{NaPO}_{3}\right)_{6} \cdot \mathrm{NaO} / 1 \mathrm{~mol} \mathrm{~L}^{-1} \mathrm{NaOH}$ by overnight shaking. BET $\mathrm{N}_{2}$ adsorption method was used to measure the specific surface area (SSA). ${ }^{47}$ Kaolinite and gibbsite contents were semi-quantified by differential termal analysis (DTA) in deferrified clay fraction free of organic matter. ${ }^{48}$ Soil attributes are given in Table 1.

\section{Batch mode adsorption studies}

Adsorption laboratory batch type experiments were carried out after adding $30 \mathrm{~mL} \mathrm{Ca}\left(\mathrm{NO}_{3}\right)_{2}$ electrolytic solution, containing $\mathrm{Cu}$ as hydrated nitrate salt $\left[\mathrm{Cu}\left(\mathrm{NO}_{3}\right)_{2} \cdot 3 \mathrm{H}_{2} \mathrm{O}\right]$, to $3.00 \mathrm{~g}$ of fine earth air dried (1:10 soil:solution ratio). The set was placed in polyethylene flasks and shaked at $150 \mathrm{osc} \mathrm{min}^{-1}$ for $24 \mathrm{~h}$ at $24 \pm 2^{\circ} \mathrm{C}$. The suspension was filtered and the remaining $\mathrm{Cu}$ concentration was determined by flame atomic absorption spectrometry. Adsorption isotherms were elaborated for soil samples at the natural $\mathrm{pH}$ (control) from experiments with increasing $\mathrm{Cu}$ concentrations ranging from 5.0 to $200.0 \mathrm{mg} \mathrm{L}^{-1}$ and $\mathrm{Ca}\left(\mathrm{NO}_{3}\right)_{2} 0.01 \mathrm{~mol} \mathrm{~L}^{-1}$ as electrolyte support. Under similar experimental conditions, adsorption envelopes were constructed by the ratio $\% \mathrm{Cu}_{\text {ads }}$ vs. $\mathrm{pH}$, after adjusting the $\mathrm{pH}$ by adding $4 \mathrm{~mol} \mathrm{~L}^{-1}$ $\mathrm{HCl}$ or $\mathrm{NaOH}$ in the suspensions containing $5 \mathrm{mg} \mathrm{L}^{-1} \mathrm{Cu}$ in $0.01,0.1$ and $1.0 \mathrm{~mol} \mathrm{~L}^{-1} \mathrm{Ca}\left(\mathrm{NO}_{3}\right)_{2}$ electrolyte support, for the simultaneous assessment of the $\mathrm{pH}$ and ionic strength effects on the $\mathrm{Cu}$ adsorption reaction. Previous trials were carried out to verify the volume of $0.04,0.4$ and $4.0 \mathrm{~mol} \mathrm{~L}^{-1}$ $\mathrm{HCl}$ and $\mathrm{NaOH}$ solutions to be added to reach the desired $\mathrm{pH}$ variation (3.0 to 8.0), so as not to exceed $2 \%$ of the volume of the electrolyte support. Analytical high-purity $\left(\right.$ Merck $\left.^{\circledR}\right)$ grade reagents were used throughout. Solutions were prepared using deionized water and all determinations were run in triplicate.

The quantity of $\mathrm{Cu}$ adsorbed, $[\mathrm{Cu}]_{\text {ads }}$, and the adsorption percentage, $\% \mathrm{Cu}_{\text {ads }}$, were calculated by the following ratios, respectively: 
$[\mathrm{Cu}]_{\mathrm{ads}}=\frac{\left([\mathrm{Cu}]_{0}-[\mathrm{Cu}]_{\mathrm{eq}}\right) \mathrm{V}}{\mathrm{m}}$

$\% \mathrm{Cu}_{\mathrm{ads}}=\frac{\left([\mathrm{Cu}]_{0}-[\mathrm{Cu}]_{\mathrm{eq}}\right)}{[\mathrm{Cu}]_{0}} \times 100$

where $[\mathrm{Cu}]_{\mathrm{ads}}$ is the quantity of $\mathrm{Cu}$ adsorbed after equilibrium $\left(\mathrm{mg} \mathrm{kg}^{-1}\right) ;[\mathrm{Cu}]_{0}$ and $[\mathrm{Cu}]_{\mathrm{eq}}$ are the initial added and equilibrium concentrations $\left(\mathrm{mg} \mathrm{L}^{-1}\right)$, respectively; $\mathrm{V}=$ solution volume $(\mathrm{mL})$; and $\mathrm{m}=$ mass of the soil sample (g). The quantity of $\mathrm{Cu}$ originally present in soil samples, although small, was discounted in the calculation of the quantity of $\mathrm{Cu}$ adsorbed.

Adsorption isotherms $\left([\mathrm{Cu}]_{\mathrm{ads}}\right.$ vs. $\left.[\mathrm{Cu}]_{\mathrm{eq}}\right)$ were constructed from the experimental results, and the $\mathrm{Cu}$ adsorption was compared with that estimated by the nonlinear form of the Langmuir isotherm:

$\mathrm{Cu}_{\mathrm{ads}}=\frac{\mathrm{K}_{\mathrm{L}} \mathrm{C}_{\mathrm{eq}} \mathrm{Ads}_{\mathrm{max}}}{1+\mathrm{K}_{\mathrm{L}} \mathrm{C}_{\mathrm{eq}}}$

where $\mathrm{K}_{\mathrm{L}}$ is the parameter related to soil affinity for $\mathrm{Cu}\left(\mathrm{L} \mathrm{kg}^{-1}\right)$ and $\mathrm{Ads}_{\max }$ is the maximum $\mathrm{Cu}$ adsorption capacity $\left(\mathrm{mg} \mathrm{kg}^{-1}\right)$. Langmuir isotherm was fitted to the $\mathrm{Cu}$ adsorption results by the Fitfunc program, ${ }^{6}$ which uses the non-linear optimization of the least squares and does not require the linearization of the isotherm, that avoids both the introduction of changes in the error distribution and the acquisition of influenced parameters $\left(\mathrm{K}_{\mathrm{L}}\right.$ and $\left.\operatorname{Ads}_{\text {max }}\right) .35,49$

\section{Thermodynamic parameters of $\mathrm{Cu}$ adsorption reaction}

In most studies, adsorption is modeled in function of temperature to obtain the reaction enthalpy. ${ }^{32}$ Some studies with trace metals have shown that the adsorption mechanism, including the intensity of the process (measured by the Langmuir Ads ${ }_{\text {max }}$ parameter) was slightly altered by temperature, and generally any conclusion made about the phenomenon at $25^{\circ} \mathrm{C}$ applies equally well to other temperatures. ${ }^{50}$ Studies on the thermodynamics of the adsorption reaction consider the activity of the element instead of the concentration, to obtain the standard thermodynamic equilibrium constant $\left(\mathrm{K}_{\mathrm{c}}{ }^{\circ}\right)$ of the system: ${ }^{32}$

$$
\mathrm{K}_{\mathrm{c}}^{\circ}=\frac{\mathrm{a}_{\mathrm{ads}}}{\mathrm{a}_{\mathrm{sol}}}
$$

where $\mathrm{a}_{\text {ads }}$ and $\mathrm{a}_{\text {sol }}$ represent the activity of the chemical species in the adsorption phase and in solution, respectively. In this experiment, the activity coefficients were taken as unitary, due to the low solute concentration (5.0 to $200.0 \mathrm{mg} \mathrm{L}^{-1}$ ) and the negligible ionic strength of the electrolyte support $\left[0.01 \mathrm{~mol} \mathrm{~L}^{-1} \mathrm{Ca}\left(\mathrm{NO}_{3}\right)_{2}\right]$, as the Debye-
Hückel equation predicts. ${ }^{51}$ The activity, a, is related to the concentration, $\mathrm{C}$, by the expression:

$\mathrm{a}=\gamma_{ \pm} \mathrm{C}$

and if the mean coefficient of the ion activity, $\gamma_{ \pm}$, is equal to the unit, equation 4 can be re-written as: ${ }^{.2}$

$\mathrm{K}_{\mathrm{eq}}=\frac{\mathrm{q}_{\mathrm{eq}}}{\mathrm{C}_{\mathrm{eq}}}$

where $\mathrm{K}_{\mathrm{eq}}$ is the apparent thermodynamic equilibrium constant of the system.

With the use of diluted solutions, whose activity coefficients are close to the unit (equation 5), the system follows the ideally diluted solution model for which the effects of differentiated interactions between the solvent and the solid unit can be disregarded, as guaranteed by the Henry's law. For these solutions, the $\mathrm{K}_{\mathrm{c}}{ }^{\mathrm{o}}$ standard equilibrium constant can be considered equivalent to the apparent equilibrium constant $\left(\mathrm{K}_{\mathrm{eq}}\right){ }^{53}$ The equivalency between $\mathrm{K}_{\mathrm{c}}{ }^{\circ}$ and $\mathrm{K}_{\mathrm{eq}}$ can be represented by the exchange reaction of $\mathrm{Ca}$ for $\mathrm{Cu}$ on kaolinite surface: ${ }^{23}$

$[$ kaolinite $] \mathrm{Ca}+\mathrm{Cu}_{\mathrm{sol}}^{2+} \stackrel{\mathrm{K}_{\mathrm{eq}}}{=}[\mathrm{kaolinite}] \mathrm{Cu}+\mathrm{Ca}_{\mathrm{sol}}^{2+}$

The equilibrium constant for the reaction is:

$\mathrm{K}_{\mathrm{eq}}=\frac{\left[\mathrm{Ca}^{2+}\right]_{\mathrm{sol}}}{\left[\mathrm{Cu}^{2+}\right]_{\mathrm{sol}}}=\frac{\mathrm{X}}{\mathrm{C}_{0}-\mathrm{X}}=\frac{\mathrm{X}}{\mathrm{C}}$

where: $\mathrm{C}_{0}$ is the initial $\mathrm{Cu}$ concentration and $\mathrm{X}$ is the adsorbed $\mathrm{Cu}$ concentration, which in turn is equal to the concentration of desorbed Ca.

The contact between solid phase and the species present in solution can occur under conditions of equilibrium or not and, ${ }^{51}$ in both cases, adsorption reactions can be described mathematically by the Gibbs free energy variation: ${ }^{23,33-35}$

$\Delta \mathrm{G}=\mathrm{RT}\left(\log \mathrm{C}_{\mathrm{eq}}-\log \mathrm{C}_{0}\right)$

where $\Delta \mathrm{G}$ is the variation of the free energy $\left(\mathrm{J} \mathrm{mol}^{-1}\right)$; $\mathrm{R}$ is the universal constant of the gases, $8.314 \mathrm{~J} \mathrm{~mol}^{-1} \mathrm{~K}^{-1}$; $\mathrm{T}$ is the absolute temperature $(\mathrm{K})$; and the difference $\left(\log \mathrm{C}_{\mathrm{eq}}-\log \mathrm{C}_{0}\right)$ represents the equilibrium constant of equation 8 .

Characteristics of the Langmuir isotherm can be expressed in terms of the separation factor or equilibrium parameter, $\mathrm{K}_{\mathrm{R}}$, a one-dimensional constant that indicates whether the adsorption reaction was favorable or not, by the ratio: $:^{35,54,55}$

$\mathrm{K}_{\mathrm{R}}=\frac{1}{1+\mathrm{K}_{\mathrm{L}} \mathrm{C}_{0}}$ 
where $\mathrm{K}_{\mathrm{L}}$ is the affinity constant estimated by the Langmuir equation (equation 3).

\section{Results and Discussion}

\section{Soil attributes}

The Oxisol subsoil samples presented ZPSE values greater than the $\mathrm{pH}$ of the soil and resulted in a positive equilibrium charge, as confirmed by the $\Delta \mathrm{pH}$ values. In the first $125 \mathrm{~cm}$ of depth, the Oxisols also presented effective cation exchange capacity (ECEC) less than $15 \mathrm{mmol}_{\mathrm{c}} \mathrm{kg}^{-1}$ of clay and $\mathrm{pH}_{\mathrm{KCl}} \geq 5.0$, meeting the requirements for the manifestation of the acric properties. ${ }^{40}$ These soils were found close to the end of their pedogenetic development cycle. They had undergone intense desilicatization because of the prolonged weathering action that was reflected by the low ki values (Table 1).

High $\sigma_{\mathrm{H}} / \sigma_{\mathrm{O}}$ ratios showed the predominance of variable charges in the acric Oxisols, as expected because the main constituents of the solid phase of these soils are organic matter, kaolinite and $\mathrm{Fe}$ and $\mathrm{Al}$ oxides, whose surface charge varies according to $\mathrm{pH}$ and ionic strength of the system. The Rhodic Acrudox presented the highest Fe and $\mathrm{Al}$ contents extracted by sulfuric acid and by CBD-Na solutions, which corresponded to the contents present in the structure of the secondary minerals and to those regarding the crystalline forms, respectively. Rhodic Acrudox, when compared to Xanthic Acrudox and Rhodic Hapludalf, presented higher and similar contents of little crystalline iron oxides, respectively, which corresponded to the more reactive oxide species with greater specific surface.

The decrease in the $\sigma_{\mathrm{H}}$ values with depth was attributed to the decrease in organic matter content, the main source of variable negative charges in wet tropical soils. In the absence of organic matter, $\mathrm{Fe}$ and $\mathrm{Al}$ surfaces are responsible for maintaining about $50 \%$ of the reversible charges. High permanent and variable charge values were found in $\mathrm{RH}$ that conferred greater charge density. This occurred in consequence of the less advanced weathering stage of RH, whose ki value indicated less intense silica loss, justifying both its greater kaolinite contents and the occurrence of clay minerals of the 2:1 type [interstratified chloride/vermicullite and vermicullite (results not shown)], responsible not only for the manifestation of permanent charges but also for the increase in the specific surface area (SSA). Gibbsite contents were particularly high in the Oxisols, and the occurrence of this mineral has implications on the magnitude of the electrical charges, especially in the deeper horizons, where the OC contents are small. Regarding the clay fraction of the soils, Rhodic Acrudox, because it was the most weathered, presented greater crystalline $\left(\mathrm{Fe}_{\mathrm{d}}\right)$ and amorphous $\left(\mathrm{Fe}_{\mathrm{o}}\right)$ Fe oxide contents, followed by RH. Also very weathered, Xanthic Acrudox presented low oxide contents because of its smaller clay content.

\section{Adsorption isotherms at natural $\mathrm{pH}$}

Figure 1 shows $\mathrm{Cu}$ adsorption isotherms by weathered soils at the natural $\mathrm{pH}$ and constant ionic strength of $0.01 \mathrm{~mol} \mathrm{~L}^{-1} \mathrm{Ca}\left(\mathrm{NO}_{3}\right)_{2}$. Copper adsorption increased as more concentrated solutions of the metal were added (Figure 1). However, the increase in the concentration was accompanied by a decrease in adsorption, mainly in the Oxisols and much less expressively in the Alfisol. At concentrations between 1 and $10 \mathrm{mg} \mathrm{L}^{-1}$, Cu exhibit high affinity for adsorption surfaces. ${ }^{56}$ Copper adsorption process
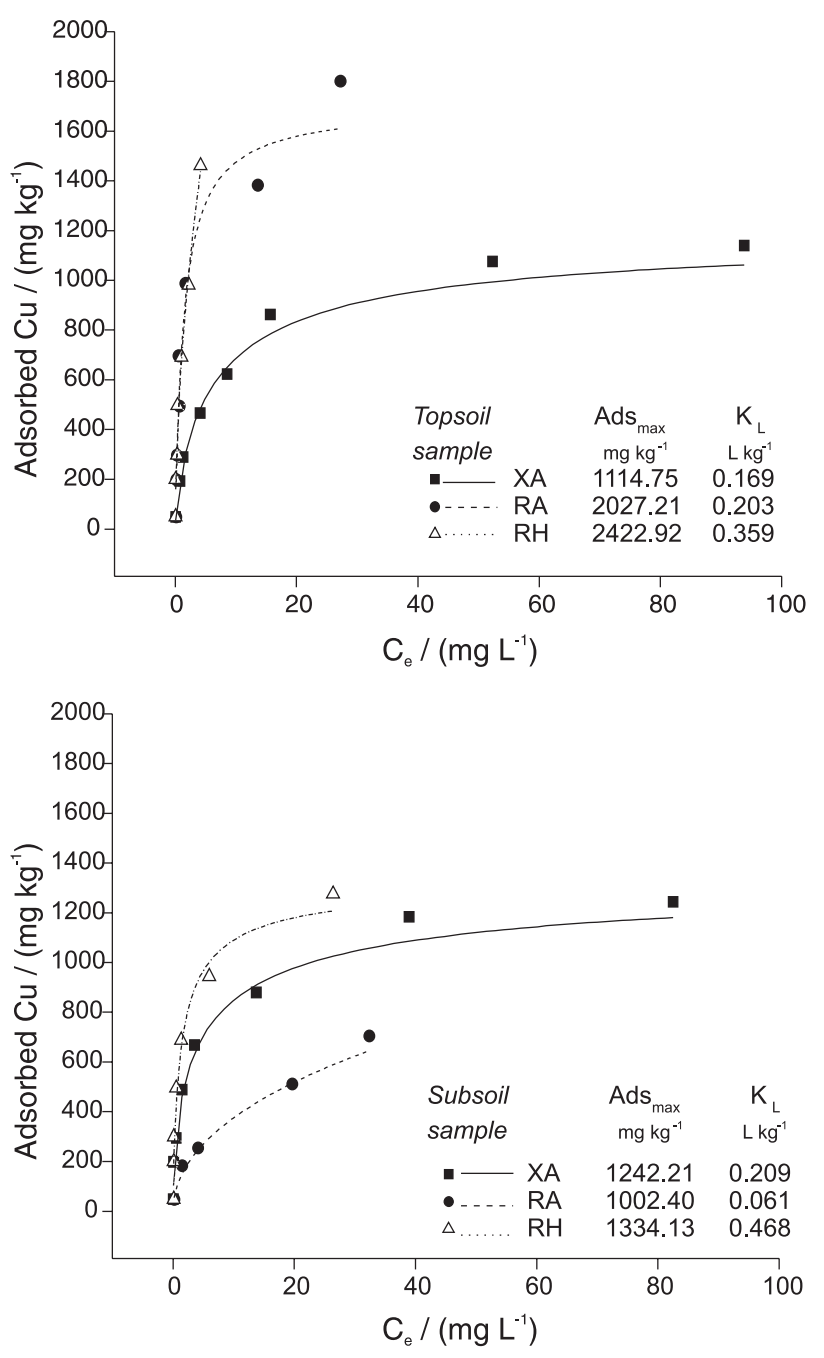

Figure 1. Isotherms and parameters of the $\mathrm{Cu}$ adsorption reaction (Ads ${ }_{\max }=$ maximum adsorption; $\mathrm{K}_{\mathrm{L}}=$ affinity constant) obtained from the fit of the Langmuir equation (curves) to the experimental results (dots); XA = Anionic "Xanthic" Hapludox; RA = Anionic 'Rhodic" Hapludox; $\mathrm{RH}=$ Rhodic Hapludalf. 
probably occurred in two stages, with the saturation of two different sets of adsorption sites. With the increase in the $\mathrm{Cu}$ concentration, more sites were occupied and retention became ever more difficult. ${ }^{24,57}$ This performance of $\mathrm{Cu}$ retention was best evaluated by categorizing of the isotherms according to their typical shape. ${ }^{58,59}$ Isotherms fitted to the Oxisols were L-type, regardless of sampling depth (Figure 1).

L-type isotherms are more commonly found in soil adsorption studies and are characterized by a small initial inclination that does not increase with the concentration of the solute in the solution. The isotherm of the RA subsoil sample could be classified as C-type, that expresses the proportional increase in the adsorption surface as adsorption increases, maintaining a constant equilibrium of the solute concentration in solid and liquid phases of the soil (Figure 1). C-type representations are typical of experimental conditions at low solute concentration. If some higher concentrations had been added, certainly the isotherm would reach its point of curvature, tending to the asymptotic performance of the L-type isotherm.

H-type adsorption isotherms were clearly identified in the RH, especially in the topsoil sample (Figure 1). The sharp initial inclination of the H-type isotherm shown by $\mathrm{RH}$ suggested high affinity of the soil for $\mathrm{Cu}$, as a result either of surface complexation mechanisms of the inner-sphere type, or significant adsorption processes mediated by van der Waals interactions. ${ }^{59}$ Normally, only the initial phase of the isotherm is characterized by a strong inclination, that corresponds to the population of sites with greater energy. ${ }^{24}$ This showed the high affinity of $\mathrm{RH}$ for $\mathrm{Cu}$, compared to the Oxisols. The adsorption of cations more strongly retained by the soil, such as $\mathrm{Cu}$ and $\mathrm{Pb}$, tend to be represented by H-type isotherms ${ }^{9}$. Nascimento and Fontes ${ }^{31}$ fitted $\mathrm{Cu}$ adsorption by Oxisols according to $\mathrm{H}$ - and L-type isotherms. Rodda et $a l .{ }^{20}$ reported that $\mathrm{Cu}$ adsorption by goethite at $\mathrm{pH} 5.0$ was characterized by a sigmoidal isotherm, that assumed the more usual shapes after $\mathrm{pH}$ 5.5.

Langmuir equation, whose original derivation considered the forces involved between the adsorbed species and the adsorption surface, leading to the formation of a monolayer of the metal on active sites of a homogeneous surface, adequately simulated the experimental results of $\mathrm{Cu}$ adsorption, according to other studies on Brazilian soils..$^{24,30,57}$ The experimental results obtained for RH showed greater adherence to the Langmuir isotherm, when compared to the Oxisols, that showed more deviations among the observed and the simulated results with increase in the $\mathrm{Cu}$ concentration added. The adsorption parameters, Ads $\mathrm{max}_{\max }$ and $\mathrm{K}_{\mathrm{L}}$, derived from the fit of the experimental results by the Langmuir isotherm, showed that $\mathrm{Cu}$ adsorption varied according to the soil and sampling depth (Figure 1). In the case of RH, the isotherms did not become asymptotic (Figure 1) and the maximum adsorption was estimated by the non-linear fit of the least squares of the Langmuir equation. Values of Ads ${ }_{\text {max }}$ of $\mathrm{Cu}$ in the topsoil and subsoil layers ranged from 1114 (XA) to $2422 \mathrm{mg} \mathrm{kg}^{-1}$ (RH) and from 1002 (RA) to $1334 \mathrm{mg} \mathrm{kg}^{-1}$ (RH), respectively (Figure 1). These values were lower than those reported by Sodré et al. ${ }^{30}$ and Silveira and Alleoni, ${ }^{24}$ but were very similar to those reported by Nascimento and Fontes. ${ }^{31}$ In the subsoil, RH maintained the greater capacity to adsorb $\mathrm{Cu}\left(1541 \mathrm{mg} \mathrm{kg}^{-1}\right)$, keeping practically the same value observed in the topsoil (Figure 1). These variations were associated with the soil type, especially to the mineralogy. Silveira et al..$^{60}$ observed that the presence of high kaolinite contents in the RH accounted completely for the $\mathrm{Cu}$ adsorption mechanisms, because the elimination of the organic matter from this soil did not cause statistical differences in the adsorption results. Except for XA, high values for Ads ${ }_{\text {max }}$ were found in topsoil samples and may be correlated with the organic carbon content (Table 1). Copper adsorption capacity of RA was reduced by half with the increase in depth. Silveira et al. ${ }^{60}$ reported considerable decrease in $\mathrm{Cu}$ adsorption after eliminating the organic matter from acric soils.

Apparently, organic matter increased $\mathrm{Cu}$ adsorption, ratifying results of some studies. ${ }^{24,31,61}$ The $\mathrm{K}_{\mathrm{L}}$ affinity constants (Figure 1), which represent the combined effect of all the reactions that occur at the solid/liquid surface, ${ }^{37}$ indicated that the affinity for $\mathrm{Cu}$ was high, both with the organic matter on the topsoil and with the oxides in the subsoil. Organic matter in the soil may act both in the solid phase of the soil, as a source of $\mathrm{pH}$ dependent changes or by the formation of $\mathrm{Cu}$ chelates, and in the soil solution, by the formation of organic $\mathrm{Cu}$ complexes, affecting its adsorption. ${ }^{12}$ Thus, organic matter does not always favor heavy metal adsorption by the soil. However, $\mathrm{Cu}$ organic complex is less toxic but offer greater risk as a pollutant because of its greater mobility. Furthermore, the organic material in the subsoil had less influence and allowed greater exposure mineral surfaces, that are hidden in topsoil because of the strict association among $\mathrm{Fe}$ and $\mathrm{Al}$ oxides, gibbsite and kaolinite with organic compounds. Surface functional groups of $\mathrm{Fe}, \mathrm{Al}$ and $\mathrm{Mn}$ oxides are very selective for $\mathrm{Cu}$ adsorption, making highly stable inner-sphere complexes. ${ }^{17,18,60,61}$

\section{Adsorption envelopes: the influence of soil $\mathrm{pH}$ on $\mathrm{Cu}$ adsorption}

Many adsorption studies with mineral soils have shown the influence of $\mathrm{pH}$ on $\mathrm{Cu}$ adsorption..$^{8-10,62,63}$ For 
oxidic interfaces, that represent well the solid-solution interface of highly weathered soils, there is a critical $\mathrm{pH}$ interval, generally smaller than two units, where the metal adsorption percentage can increase clearly from an extremely low value, in low $\mathrm{pH}$ values, to up to $100 \%$, in high $\mathrm{pH}$ values. This critical interval, known as the adsorption edge, is related to the hydrolysis constant of the metallic ions. Adsorption envelope, represented graphically by the ratio $\%$ ads $v s . \mathrm{pH}$, showed the relative removal of $\mathrm{Cu}$ from the solution, at constant ionic strength of $0.01 \mathrm{~mol} \mathrm{~L}^{-1}$ $\mathrm{Ca}\left(\mathrm{NO}_{3}\right)_{2}$ and at initial fixed $\mathrm{Cu}$ concentration of $5 \mathrm{mg} \mathrm{L}^{-1}$ (Figure 2).

Copper adsorption did not show strong dependence on the $\mathrm{pH}$ in the topsoil samples. At $\mathrm{pH} \mathrm{3.5,70-80 \%} \mathrm{of}$ the total $\mathrm{Cu}$ added was adsorbed. Adsorption increased in a small interval of one $\mathrm{pH}$ unit between 4.0 and 5.0, a range considered by Jordão et $a l .{ }^{57}$ as ideal to study
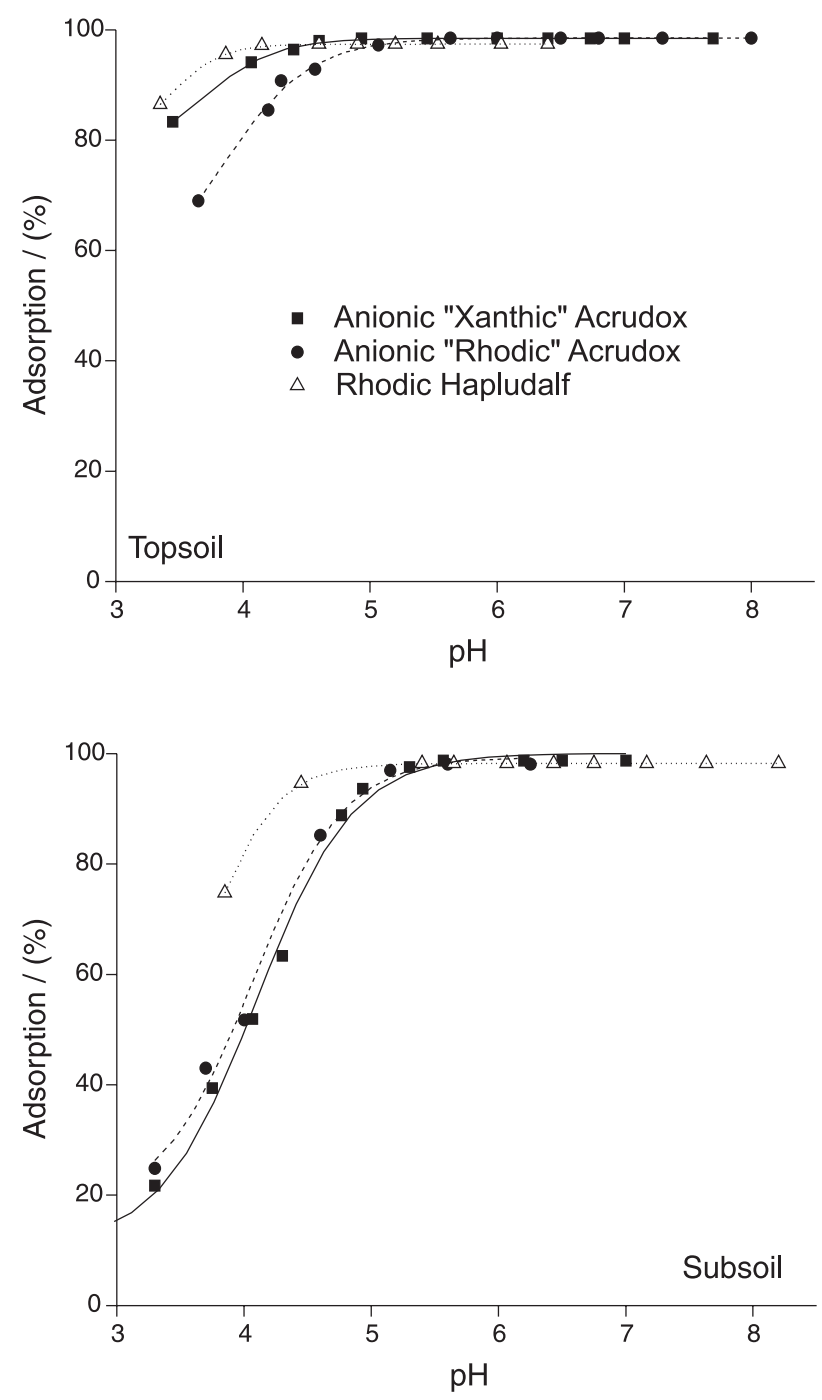

Figure 2. $\mathrm{Cu}$ adsorption envelopes for topsoil and subsoil samples of highly weathered soils. the phenomenon of metal retention. Over $\mathrm{pH}$ 5.0, all $\mathrm{Cu}$ initially added disappeared from the soil solution. Cavallaro and $\mathrm{McBride}^{8}$ reported that in soils with $\mathrm{pH}$ less than $2.5, \mathrm{Cu}$ competed with protons for adsorption sites. However, at $\mathrm{pH}$ over 4.5 , more charged sites were available for $\mathrm{Cu}$, due to the decrease in competition for protons, while at $\mathrm{pH}$ between 4.0 and 6.0, $\mathrm{Fe}$ and $\mathrm{Al}$ oxides were the main causes of fixation and solubilization. ${ }^{8}$ Barrow et al..$^{27}$ reported that $\mathrm{Cu}$ tended to be adsorbed at $\mathrm{pH}$ values lower than $\mathrm{Cd}, \mathrm{Zn}$ and $\mathrm{Co}$. The degree by which the metals are hydrolyzed is probably the main factor that determines the quantity of metal retained at a given $\mathrm{pH} .{ }^{12}$ Adsorption can vary drastically because of the different metal species (e.g. $\mathrm{Cu}^{2+}$ compared with $\mathrm{CuOH}^{+}$) and organic complexing can increase, suppress or present imperceptible effect on metal adsorption, depending on the $\mathrm{pH}$. The effect of organic anions on $\mathrm{Cu}$ adsorption performance in soils with variable charges is still little understood and, although it is very difficult to generalize about the influence of organic complexing on metal adsorption, it is known that the organic treatments widely influence $\mathrm{Cu}$ adsorption. ${ }^{26}$ Increase in the $\mathrm{pH}$ generally decreases the quantity of $\mathrm{Cu}$ organically complexed in the soil solution, that means alterations for species with greater affinity for adsorption. ${ }^{63}$ Rodda et al. ${ }^{20}$ presumed that $\mathrm{Cu}^{2+}, \mathrm{Cu}(\mathrm{OH})^{+}$and $\mathrm{Cu}_{2}(\mathrm{OH})_{2}{ }^{2+}$ were the dominant species that compete for adsorption sites on the goethite surface. Hydrolyzed species are preferentially adsorbed and thus the first hydrolysis product, $\mathrm{MOH}^{+}$, is usually in the predominant concentration. ${ }^{23,64}$ However, Rodda et $a l .{ }^{20}$ concluded that the dimer species $\left[\mathrm{Cu}_{2}(\mathrm{OH})_{2}{ }^{2+}\right]$ were the main hydrolysis product in the $\mathrm{pH}$ interval where accelerated adsorption occurred.

The proportion of adsorbed ions increased uniformly and continually with the increase in the $\mathrm{pH}$, but the shape of the curve and its position depended on the soil identity, especially regarding its mineralogical constitution (Figure 2). The adsorption pattern was very similar for the Oxisols samples, as shown by the shape and position of the adsorption edges (Figure 2), even when overlapped in the case of the Oxisol subsoil samples (Figure 2). The adsorption edges that represented $\mathrm{Cu}$ adsorption by the Oxisols subsoil samples exhibited the typical sigmoid shape (Figure 2). The atypical shape of the adsorption edge of topsoil and subsoil RH samples suggested that $\mathrm{Cu}$ adsorption was qualitatively different. For a given type of adsorption surface, the adsorption edge is a function of the affinity and normally it is argued that this affinity is high when adsorption occurs at low $\mathrm{pH}$ values, as verified for RH, in the subsoil, and for all topsoil samples (Figure 2). 


\section{Thermodynamic approach of $\mathrm{Cu}$ adsorption reaction}

Theoretical description of the solid/solution interface and of $\mathrm{Cu}$ adsorption

The application of thermodynamics to describe phenomena requires selection of the studied system, which means isolating parts of the universe of interest to a restriction level that does not permit the transference of energy to the medium that surrounds it. Under field conditions, the soil performs as a very dynamic system, and the need to isolate the system is only met under controlled laboratory conditions. For didactic purposes, the soil is considered a system composed of the solid, liquid and gaseous phases, but while useful for some purposes, this concept does not characterize a chemical, physically homogeneous and mechanically separable region, understood by thermodynamics as phase.

These considerations explain the absence of criteria to apply thermodynamic parameters in heterogeneous systems such as the soil. ${ }^{32,51}$ As normally the liquid phase also does not meet the requirement of homogeneity, it is admitted that the solid solution system, whose interface is of interest because it bases the chemical reactions that govern metal bioavailability, it is in a constant state of lack of equilibrium. However, this apparent imbalance does not imply neglecting the thermodynamic bases, whose principles allow the determination of which processes are more energetically favorable, even in dynamic systems such as the soil. ${ }^{51}$

Although the soil is considered a complex system, its mineral composition becomes more simplified when exposed to prolonged conditions of high temperature and humidity. Extreme weathering conditions intensify the desilicatization and favor the accumulation of $\mathrm{Fe}$ and $\mathrm{Al}$ oxides, which together with kaolinite, are typical minerals of weathered soils in the wet tropics (Table 1). Electrical charges develop on the surface of these minerals either by the dissociation of $\mathrm{H}^{+}$ions from the surface hydroxyl groups or by the combination of these groups with $\mathrm{H}^{+}$ions present in the solution: ${ }^{65}$

$$
\mathrm{M}-\mathrm{OH}_{2}^{+} \underset{+\mathrm{H}^{+}}{\stackrel{-\mathrm{H}^{+}}{\leftrightarrow}} \mathrm{M}-\mathrm{O} \underset{+\mathrm{H}^{+}}{\stackrel{-\mathrm{H}^{+}}{\leftrightarrow}} \mathrm{M}-\mathrm{O}^{-}
$$

where $\mathrm{M}$ represents a metal ( $\mathrm{Fe}$ or $\mathrm{Al}$ ) of an oxide structure, generating charged $\mathrm{Fe}-\mathrm{OH}$ or $\mathrm{Al}-\mathrm{OH}$ groups. The amphoteric performance, that is, the reversibility capacity of charges, is characteristic of soil oxides, because the loss or the incorporation of an $\mathrm{H}^{+}$ions can charge the surface negatively or positively (equation 11).

Although there are about 80 metallic elements in the periodic table, only 20-30 ions can exist independently in the aquometal form, that is, partially hydrolyzed metallic ions, in the soil solution. ${ }^{12}$ Electropositive metals, when in contact with the water solution, are aquocomplexed from a simple hydrolysis reaction:

$\mathrm{M}_{(\mathrm{aq})}^{+}+\mathrm{xH}_{2} \mathrm{O} \leftrightarrow \mathrm{M}\left(\mathrm{H}_{2} \mathrm{O}\right)_{\mathrm{x}(\mathrm{aq})}^{+}$

Transition metals, such as $\mathrm{Cu}$, may undergo a series of electrolytic related reactions: ${ }^{12}$

$$
\begin{aligned}
& \mathrm{M}\left(\mathrm{H}_{2} \mathrm{O}\right)_{\mathrm{x}}^{\mathrm{m}+} \stackrel{\mathrm{pK}}{\longrightarrow}\left[\mathrm{M}\left(\mathrm{H}_{2} \mathrm{O}\right)_{\mathrm{x}-\mathrm{y}}(\mathrm{OH})_{\mathrm{y}}\right]^{(\mathrm{m}-\mathrm{y})}+\mathrm{yH}^{+} \\
& \mathrm{M}\left(\mathrm{H}_{2} \mathrm{O}\right)_{\mathrm{x}}^{\mathrm{m}+} \stackrel{\mathrm{pK}=9,6}{\longleftrightarrow}\left[\mathrm{M}\left(\mathrm{H}_{2} \mathrm{O}\right)_{\mathrm{x}-\mathrm{y}}(\mathrm{OH})_{y}\right]^{(m-y)}+\mathrm{yH}^{+}
\end{aligned}
$$

where $\mathrm{m}$ is the metal charge, $\mathrm{z}$ is the coordination number, related to the number of the solvation molecules, and $y$ is the quantity of $\mathrm{H}^{+}$released. Thermodynamic studies on the adsorption reaction generally consider all the reactions involved, that include hydrolysis in solution and subsequent adsorption of the products of this reaction. ${ }^{20}$

The complete description of the system culminates in the interaction between the solid phase and the metallic species present in the liquid phase, which is established by the adsorption phenomenon. Metal adsorption is not necessarily a single process, that involves one species, one equilibrium or one mechanism. ${ }^{64}$ Copper can be adsorbed electrostatically (outer-sphere complex), it can be specifically adsorbed on the $\mathrm{Fe}$ and $\mathrm{Al}$ (oxy)hydroxides surfaces (inner-sphere complex) or it can be complexed by organic matter: ${ }^{66}$

Outer-sphere complexes between bivalent hydrated metal ions and $\mathrm{pH}$ dependent charged sites:

] $\left.-\mathrm{OH}+\mathrm{OH}^{-}+\mathrm{M}\left(\mathrm{H}_{2} \mathrm{O}\right)_{n}^{2+} \rightarrow\right]-\mathrm{O}^{-} \cdots \mathrm{M}\left(\mathrm{H}_{2} \mathrm{O}\right)_{n}^{2+}+\mathrm{H}_{2} \mathrm{O}$

Inner-sphere complexes at the variable charged sites

]$\left.-\mathrm{OH}+\mathrm{OH}^{-}+\mathrm{M}\left(\mathrm{H}_{2} \mathrm{O}\right)_{n}^{2+} \rightarrow\right]-\mathrm{O}-\mathrm{M}\left(\mathrm{H}_{2} \mathrm{O}\right)_{n-1}^{+}+2 \mathrm{H}_{2} \mathrm{O}$

Chelated complexes between metal and amino acid group in the organic matter: ${ }^{67}$

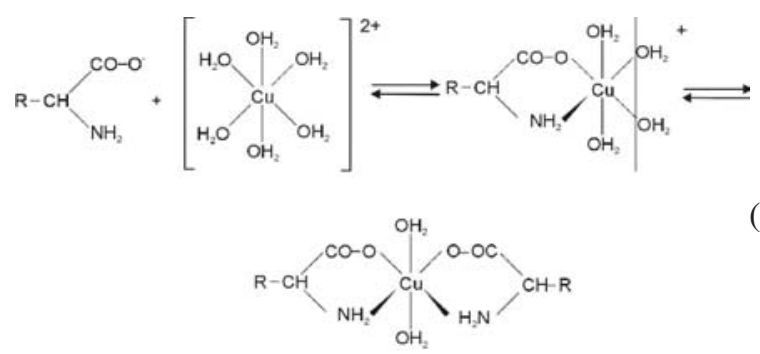

where ... represents weak attraction of the metal ion to the oxide surface. 
The process described by equation 16 has been identified as the one that occurs most frequently in $\mathrm{Cu}$ adsorption on inorganic surfaces, while equation 17 shows the strong interaction of $\mathrm{Cu}$ with organic matter compounds. ${ }^{23,61}$ It is a slow reversibility reaction under natural conditions, since it is a process that involves much energy because of the partially covalent links (inner-sphere) with the structural metal cations of the surface. ${ }^{49}$

The thermodynamic approach of a system, whether in equilibrium or not, requires that the transformations it undergoes be mediated by reversible processes. However, reversibility is an ideal concept that can never be reached because, theoretically, it should take an infinite time to occur. However, reversibility of the interaction between $\mathrm{Cu}$ and the different adsorption surfaces has not yet been clarified, because while for some soils the adsorption isotherm corresponded to the desorption isotherm, in others the $\mathrm{Cu}$ desorption was hysteretic. ${ }^{25}$ The manifestation of charges on the amphoteric colloidal surfaces, such as the $\mathrm{Fe}$ and $\mathrm{Al}$ oxides, occurred through reversible processes that depended on the soil solution $\mathrm{pH}$ (equation 11). However, the nature of the $\mathrm{Cu}$ species that occurred in the soil solution was also directly dependent on the $\mathrm{pH}$ of the system (equations 12 , 13 and 14). Thus the two components of the soil solution system, that is, the colloids and $\mathrm{Cu}$ species in solution, have modifications of a reversible nature, through the influence of the $\mathrm{pH}$. Which must be thoroughly clarified is that even though $\mathrm{Cu}$ adsorption is mediated by more energetic reactions, in systems of variable electric charges these phenomena can be reversed by alterations in the $\mathrm{pH}$, and in this way, the reversibility of the $\mathrm{Cu}$ adsorption reaction by soils with variable charges meets the requirements of thermodynamics.

\section{Thermodynamic parameters of $\mathrm{Cu}$ adsorption reaction}

\section{Separation factor $\left(K_{R}\right)$}

Preliminary data concerning the degree of development and spontaneity of the adsorption reaction can be obtained from assessing $\mathrm{K}_{\mathrm{R}}$ separation factor (equation 10), calculated from the $\mathrm{K}_{\mathrm{L}}$ Langmuir constant (equation 3). According to a more simplified approach, ${ }^{35,55}$ adsorption is favorable and spontaneous when $\mathrm{K}_{\mathrm{R}}<1$, while values of $\mathrm{K}_{\mathrm{R}}>1$ indicate lack of spontaneity in the reaction. The $\mathrm{K}_{\mathrm{R}}$ coefficient can further indicate whether the adsorption isotherm is unfavorable to the process $\left(\mathrm{K}_{\mathrm{R}}>1\right)$, linear $\left(K_{R}=1\right)$, favorable $\left(K_{R}<1\right)$ or irreversible $\left(K_{R}=0\right){ }^{54}$

The $\mathrm{K}_{\mathrm{R}}$ values decreased with the increase in the initial $\mathrm{Cu}$ concentration and were always less than 1 (Figure 3), confirming some results obtained for metal cation reactions. ${ }^{54}$
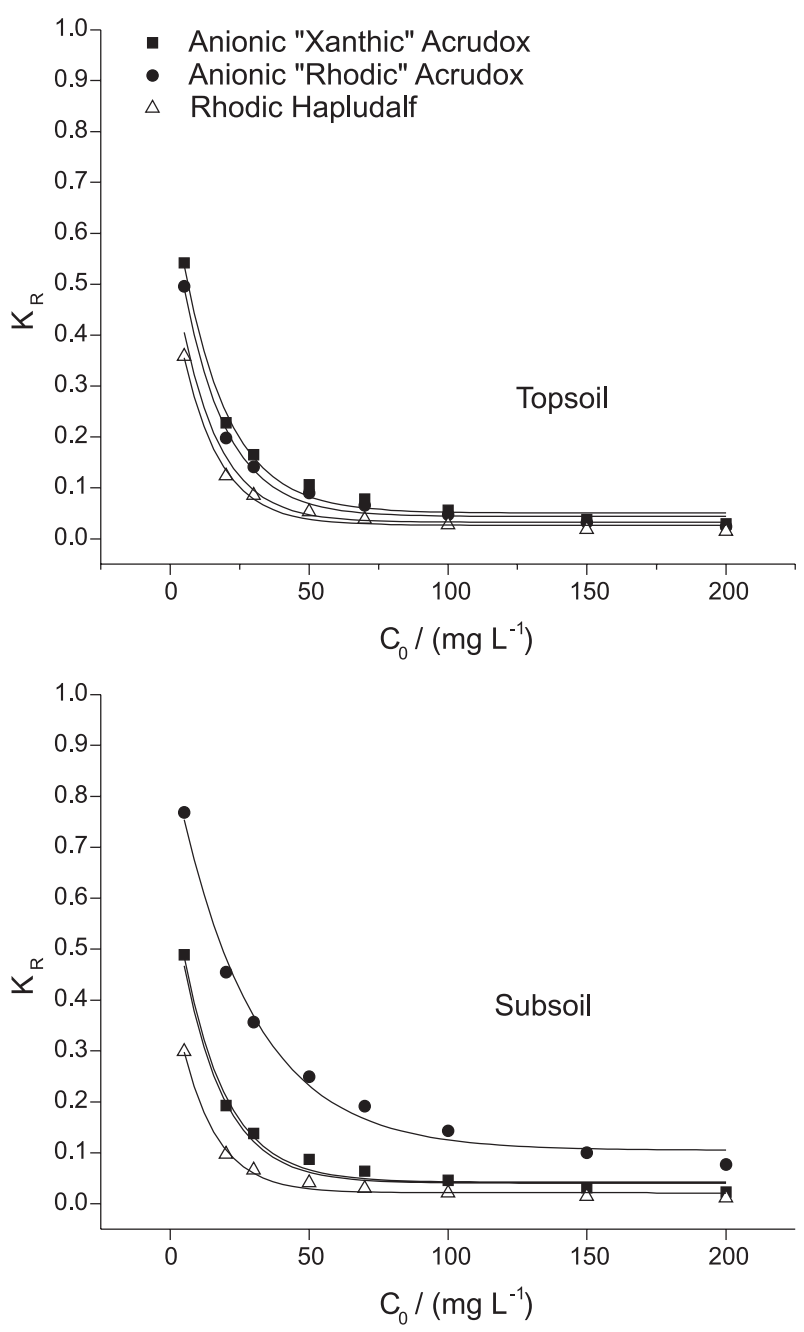

Figure 3. Separation factor $\left(\mathrm{K}_{\mathrm{R}}\right)$ as a function of the added $\left(\mathrm{C}_{0}\right) \mathrm{Cu}$ concentration to the soils, at natural $\mathrm{pH}$.

This indicated that the adsorption reaction was more favorable for high initial $\mathrm{Cu}$ concentrations $\left(\mathrm{C}_{0}\right)$ and that it was processed spontaneously, further indicating that all the soils had good systems for $\mathrm{Cu}$ retention, in the following order: $\mathrm{RH}>\mathrm{RA}=\mathrm{XA}$, on the topsoil, and $\mathrm{RH}>\mathrm{XA}>\mathrm{RA}$, in the subsoil. Except for RA, the separation factor was not a very sensitive parameter for sampling depth (Figure 3). For RA, $\mathrm{K}_{\mathrm{R}}$ values were lower for the topsoil samples, indicating that $\mathrm{Cu}$ adsorption developed more spontaneously in the presence of organic matter.

The $\mathrm{K}_{\mathrm{R}}$ parameter is sensitive to the hydrated radius of the ions ${ }^{35}$ and under conditions that the adsorption experiments to construct isotherms were carried out, that is, at natural $\mathrm{pH}$ of the samples ( $\mathrm{pH}$ between 4.0 and 5.5), low $\mathrm{K}_{\mathrm{R}}$ values seemed to be in line with the predominance of $\mathrm{Cu}$ hydroxilated species, whose hydration radius was less than the $\mathrm{Cu}$ free species, or further with the occurrence of specific $\mathrm{Cu}$ adsorption mechanisms, because the formation of inner-sphere-type complexes did not allow 
the interposition of water molecules on the solid-solution interface and justified the adsorption of species with smaller hydration radius and quantitatively characterized by low $\mathrm{K}_{\mathrm{R}}$ values (Figure 3).

Variation in Gibb's free energy $(\Delta G)$ of $C u$ adsorption reaction

$\Delta \mathrm{G}$ indicates the degree of spontaneity of the adsorption process, and the highest values (in module) reflect a more energetically favorable adsorption reaction. The negative
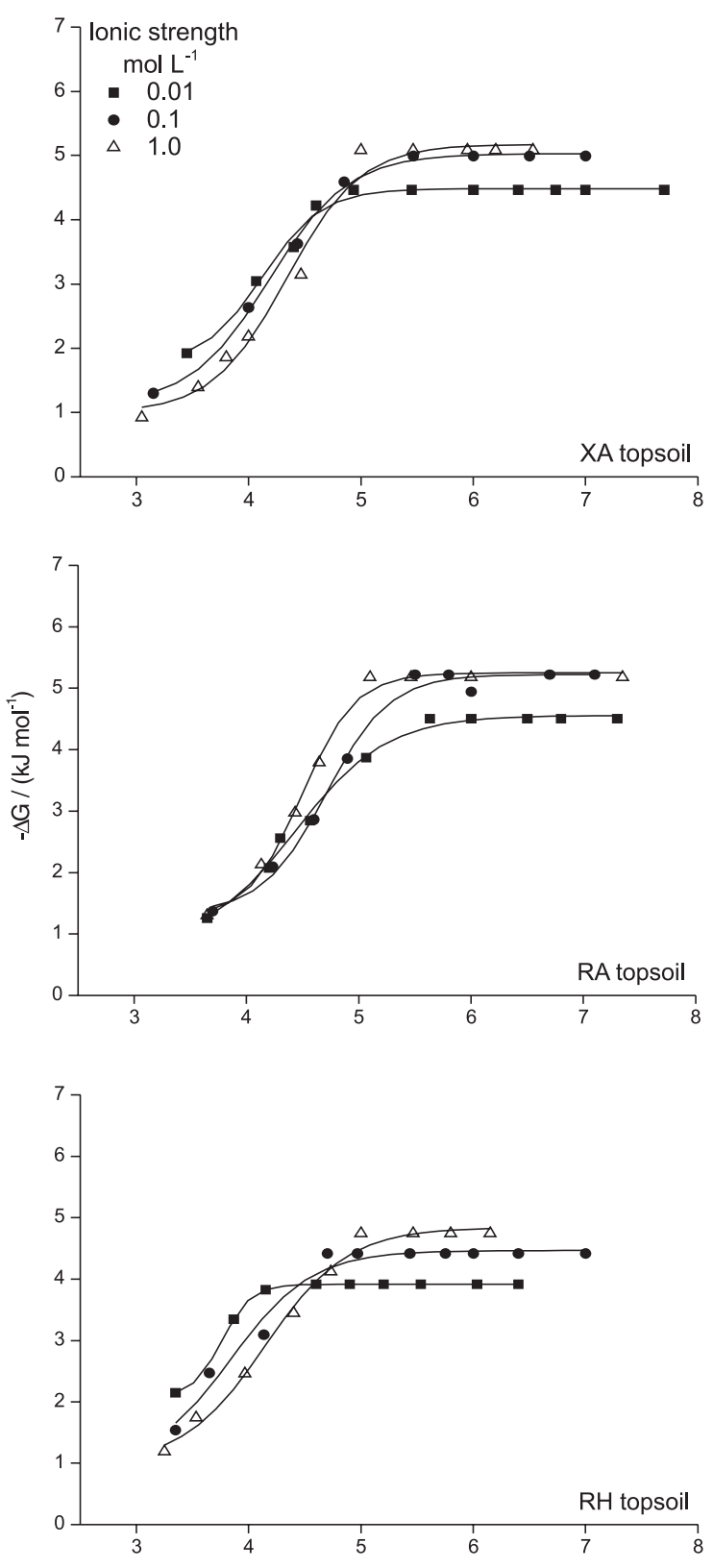

Figure 4. Effect of soil solution parameters ( $\mathrm{pH}$ and ionic strength) on the free energy of the $\mathrm{Cu}$ adsorption reaction by weathered soils.
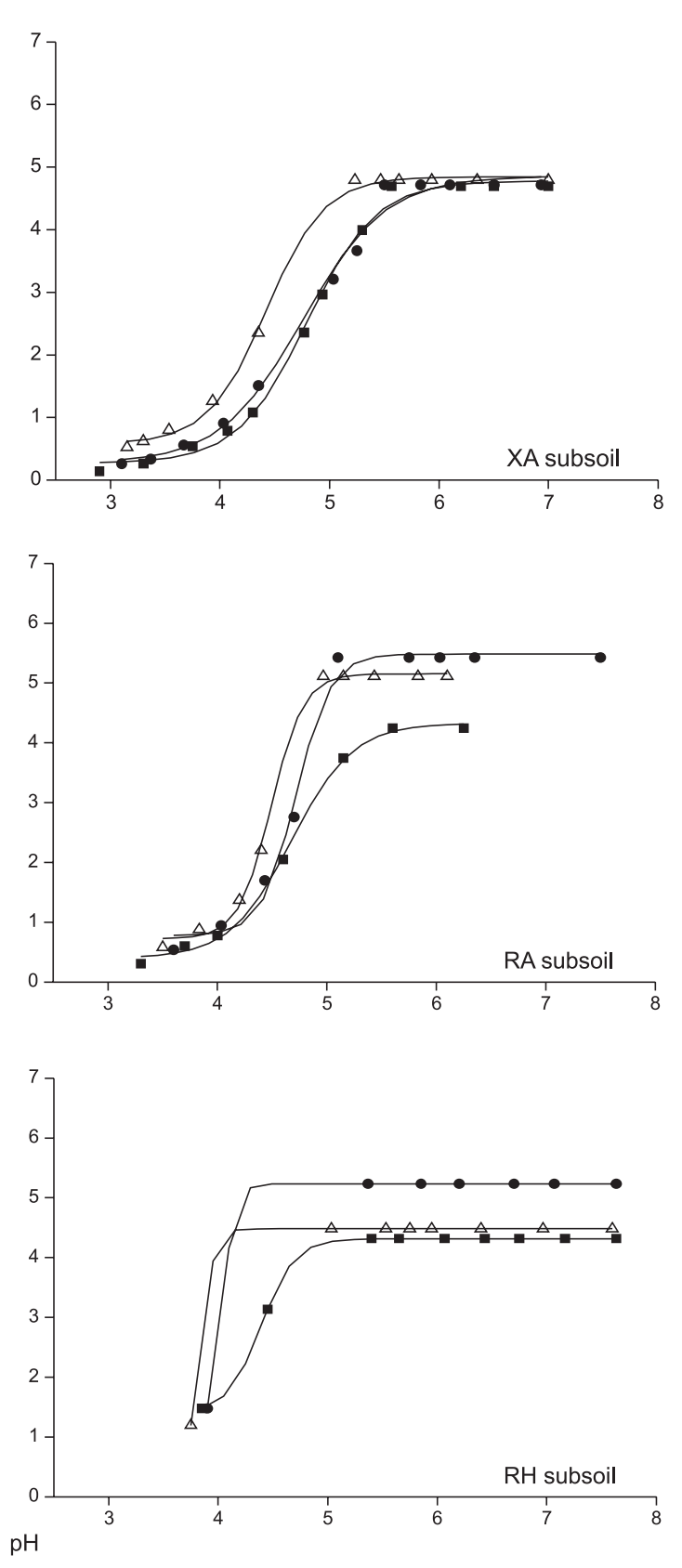

$\Delta \mathrm{G}$ values (Figure 4) were coherent with the $\mathrm{K}_{\mathrm{R}}$ values (Figure 3) and confirmed the viability and the spontaneous nature of $\mathrm{Cu}$ adsorption by highly weathered soils. The adsorption reaction is generally spontaneous for metal elements by organic and inorganic surfaces of pure or isolated systems. ${ }^{23}$ The spontaneity of the $\mathrm{Cu}$ adsorption reaction by weathered soils, similar to $\mathrm{Cd}$ and $\mathrm{Zn}$ by synthetic oxidic surfaces, ${ }^{38}$ was characterized by negative free energy values of the reaction.

When increasing concentrations of the elements are added to the soil, the $\Delta \mathrm{G}$ value can show the magnitude of 
the extension of the reaction between the elements and the adsorption surfaces. ${ }^{33,35}$ Thus, negative $\Delta G$ values implied that the reaction should be occurring in the direction of product formation, that is, towards adsorption reactions. The more negative the $\Delta \mathrm{G}$, the greater is the driving force for adsorption to occur. The $\Delta \mathrm{G}$ values decreased with the increase in the quantity of $\mathrm{Cu}$ added. Doula et $a l .{ }^{23}$ considered that the initial $\mathrm{Cu}$ concentration was an important factor that influences the adsorption process, which is extremely spontaneous only at low initial $\mathrm{Cu}$ concentrations. The decrease in the free energy of the $\mathrm{Cu},{ }^{23,33} \mathrm{Cd}^{34}$ and $\mathrm{B}^{35}$ adsorption reactions by highly weathered soils with the increased concentration led to the conclusion that the more concentrated the solution, the less spontaneous the reaction became. However, the $\Delta \mathrm{G}$ values were negative for all the concentration range (Figure 4) and in addition to the reaction spontaneity, this indicated that the sorbed forms were more stable than those in solution. ${ }^{35}$

Figure 4 again shows the influence of the $\mathrm{pH}$, this time on the spontaneity of the adsorption reaction, after adding $5 \mathrm{mg} \mathrm{L}^{-1} \mathrm{Cu} . \Delta \mathrm{G}$ values increased in all the samples with the increase in the $\mathrm{pH}$, showing not only that $\mathrm{Cu}$ adsorption increased with increase in $\mathrm{pH}$ (Figure 2), but also that the reaction was favored with the decrease in the hydrogenionic concentration (Figure 4). For the $5 \mathrm{mg} \mathrm{L}^{-1}$ $\mathrm{Cu}$ concentration and $0.01 \mathrm{~mol} \mathrm{~L}^{-1} \mathrm{Ca}\left(\mathrm{NO}_{3}\right)_{2}$ ionic strength, maximum $\Delta \mathrm{G}$ values (average of the two horizons) were reached around $\mathrm{pH} 4.0$ in the Alfisol $\left(-4.1 \mathrm{~kJ} \mathrm{~mol}^{-1}\right)$ and close to the pH 5.0 in the RA $\left(-4.4 \mathrm{~kJ} \mathrm{~mol}^{-1}\right)$ and the XA $\left(-4.6 \mathrm{~kJ} \mathrm{~mol}^{-1}\right)$ (Figure 4).

Copper adsorption was also assessed regarding the alterations in the electrolyte support concentration, using the variation in the free energy as numerical parameter of the reaction (Figure 4). In the subsoil samples, to the $\mathrm{pH}$ that occurs with the maximum variation in the free energy, the $\Delta \mathrm{G}$ values increased even more when the electrolyte support concentration changed from 0.01 to $0.1 \mathrm{~mol} \mathrm{~L}^{-1}$ $\mathrm{Ca}\left(\mathrm{NO}_{3}\right)_{2}$, mainly in the XA, wich reached $-6.2 \mathrm{~kJ} \mathrm{~mol}^{-1}$. In the topsoil samples, maximum $\Delta \mathrm{G}$ values also increased with the increase in the ionic strength when the support solution of $1.0 \mathrm{~mol} \mathrm{~L}^{-1} \mathrm{Ca}\left(\mathrm{NO}_{3}\right)_{2}$ was used (Figure 4).

The dependency of metal adsorption in relation to the ionic strength can supply indications of the formation of inner and outer-sphere complexes with the colloidal surface. ${ }^{68}$ Many studies have considered the effect of cations and anions of the electrolyte support on metal adsorption, mainly regarding the competitive effect of $\mathrm{Ca}$ for adsorption sites and by the action of the anions in the formation of complexes with less affinity for the surface. ${ }^{68}$ Starting at $\mathrm{pH} 4.5$, even though it was not very apparent, it was observed that $\mathrm{Cu}$ adsorption began to become dependent on the ionic strength. Increased ionic strength may have caused the increase in the competition between $\mathrm{Ca}$ and $\mathrm{Cu}$ for electrostatic adsorption sites (equation 15). As much of the $\mathrm{Cu}$ was adsorbed at low $\mathrm{pH}$, the metal probably competed less intensely for nonspecific adsorption sites, which enhanced the effect of the ionic strength. At $\mathrm{pH}$ around 5.0, where almost all the $\mathrm{Cu}$ was adsorbed, the competition between $\mathrm{Ca}$ and $\mathrm{Cu}$ for nonspecific sites was more intense because of the higher $\mathrm{Cu}$ concentration. With the increase in the ionic strength, Ca was adsorbed preferentially by the sites because of its greater concentration. Thus, $\mathrm{Cu}$ may have been adsorbed only by specific adsorption sites that sustained the increase in the $\Delta \mathrm{G}$ values with the increase in the ionic strength, since the reaction became more spontaneous because it involved more energy (Figure 4). The absence of dependency on adsorption regarding the ionic strength was more evident in the XA samples. The adsorption dependency of the Alfisol in relation to the ionic strength was also not very evident (Figure 4), but occurred at lower $\mathrm{pH}$, because of the probable decrease in the cation repulsion in function of the manifestation of the permanent charges $\left(\sigma_{\mathrm{H}}\right)$ still present (Table 1). On the other hand, lack of dependency of metal adsorption in relation to the ionic strength gave an indication of complexing by inner- and outer-sphere mechanisms, typical of transition metal elements. Generally, specific adsorption mechanisms are accompanied by release of $\mathrm{H}^{+}$ ions to the soil solution, as a result of their displacement so that great energy linking occurs between the surface and the metal ion. Alteration in the $\mathrm{pH}$ of the final extract after adsorption may be an indication that specific adsorption had taken place with greater frequency (Figure 5).

Mesquita and Vieira e $\mathrm{Silva}^{69}$ reported that the $\mathrm{pH}$ in the equilibrium solution, after $\mathrm{Cu}$ and $\mathrm{Zn}$ adsorption, decreased as the concentration of the metal in the initial solutions increased, due to metal hydrolysis and proton release during adsorption. If it is accepted that inner- and outer-sphere complexing (equations 15 and 16) is the predominating mechanism, it seems reasonable to accept the hypothesis that, in the case of $\mathrm{Cu}$ adsorption, the effective $\mathrm{pH}$ is more critical in determining the metal species in solution because of its action on hydrolysis, and not in determining the surface charge.

The free energy of the adsorption reaction can be decomposed into three components: ${ }^{70} \Delta \mathrm{G}_{\text {coul }}$, the electrostatic component; $\Delta \mathrm{G}_{\text {chem }}$, the chemical component, and $\Delta \mathrm{G}_{\mathrm{int}}$, the interaction component, that gives more specificity to the electrostatic component, that is:

$\Delta \mathrm{G}_{\mathrm{ads}}=\Delta \mathrm{G}_{\text {coul }}+\Delta \mathrm{G}_{\text {quím }}+\Delta \mathrm{G}_{\mathrm{int}}$ 

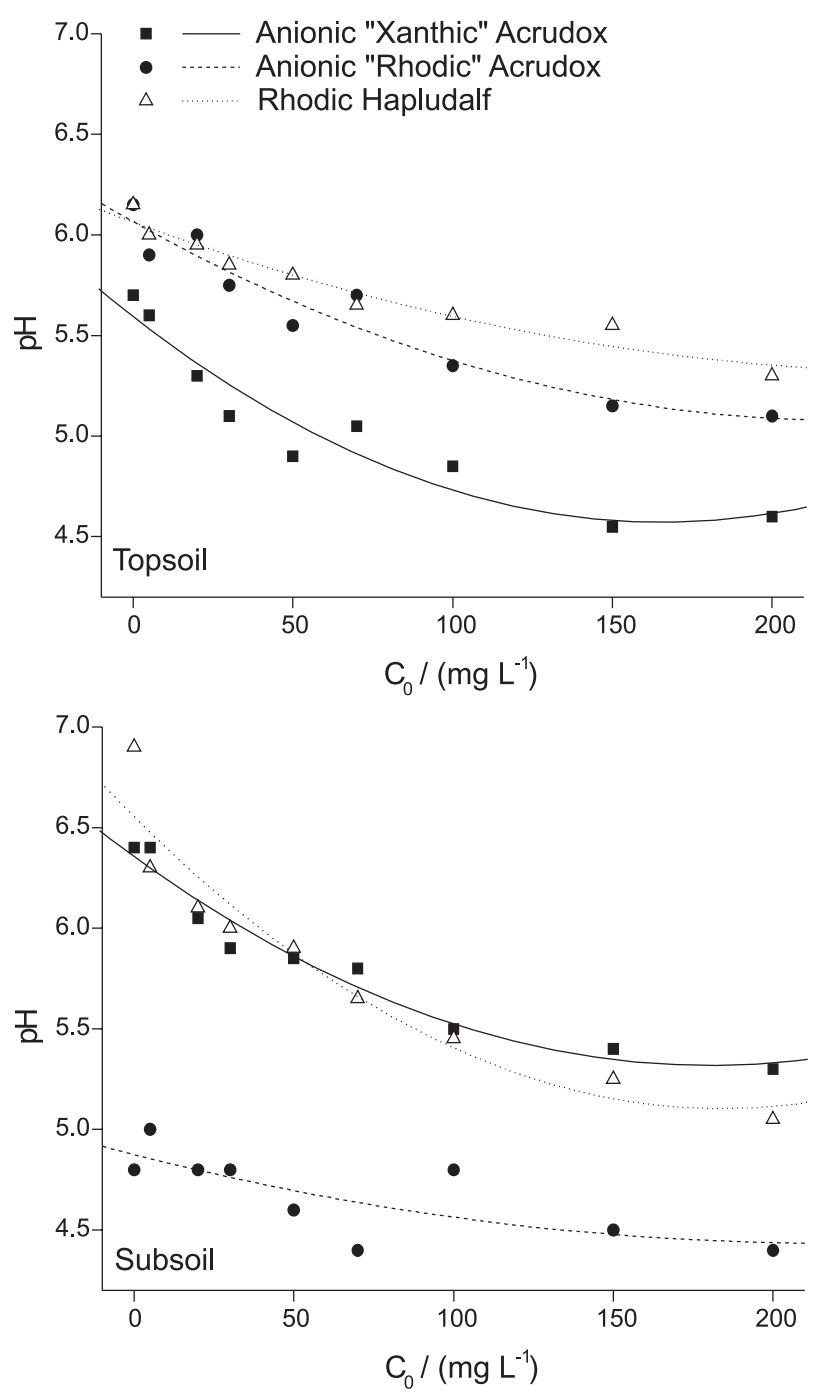

Figure 5. Final $\mathrm{pH}$ of equilibrium solution after adding increasing $\mathrm{Cu}$ concentrations.

In systems with variable electric charges, as in the case of the acric Oxisols (RA and XA), where the metal ions can be adsorbed both by electrostatic mechanisms (equation 15) or by specific mechanisms (equations 16 and 17), $\Delta \mathrm{G}_{\text {chem }}$ and $\Delta \mathrm{G}_{\text {coul }}$ are important components. ${ }^{70}$ In the case of $\mathrm{Cu}$, electrostatic forces can represent an insignificant contribution to the adsorption free energy and can be replaced by chemical reactions with the surface. Thus, the free energy of the $\mathrm{Cu}$ adsorption reaction seems better reproduced by the $\Delta \mathrm{G}_{\text {chem }}$ component.

Generally, Oxisols presented higher $\Delta \mathrm{G}$ values than Alfisols, which indicated that $\mathrm{Cu}$ adsorption was more favored in the more weathered soil. Studies on $\mathrm{Cu}$ and $\mathrm{Co}$ adsorption by kaolinite showed that the enthalpy at the variable charge sites can be seven times greater compared to the permanent charge sites,${ }^{50}$ which means that sites with variable charges are more important in metal adsorption.

\section{Conclusions}

In soils with high pollutant load, the objective of remediation treatments is to effectively reverse the bioavailability of $\mathrm{Cu}$. This study characterized and quantified the ability of extremely weathered soils to reduce the $\mathrm{Cu}$ concentration in the soil solution. Langmuir equation simulated adequately the experimental results of $\mathrm{Cu}$ adsorption and provided informative parameters of $\mathrm{Cu}$ maximum adsorption ( $\mathrm{Ads}_{\max }$ ) and affinity $\left(\mathrm{K}_{\mathrm{L}}\right)$ by the highly weathered soils. Thereby, Langmuir model can be used to prognosticate the performance of $\mathrm{Cu}$ in soils with similar attributes to those in this study. The decrease in the bioavailability of $\mathrm{Cu}$ contents in the soil solution did not show strong dependence on the $\mathrm{pH}$. Copper adsorption was high even under highly acid soil conditions, but the process was intensified with the decrease in the hydrogenionic concentration, presenting a fast and clear increase in the 4-5 $\mathrm{pH}$ interval, because of the low hydrolysis constant of the metal. Soil $\mathrm{pH}$ management as a way to remedy areas contaminated by $\mathrm{Cu}$ can be a promising technique because of it is efficient and cheap. The results of the present study indicated that highly weathered soils presented organic and mineral constituents that could reduce the $\mathrm{Cu}$ concentration in the soil solution by adsorption mechanisms. Greater soil adsorption capacity ( $\mathrm{Ads}_{\max }$ ) can be reached in the topsoil layers, because of the additional availability of adsorption sites on the surface of the organic colloids and the high affinity of $\mathrm{Cu}$ to form chelated complexes with the organic matter. In the absence of organic matter, $\mathrm{Cu}$ retention may decrease in quantitative terms, but the affinity with the soil colloids remained stable, due to the affinity with both organic and inorganic colloids, especially with the oxides. In addition chemical and mineralogical attributes, organic matter content of the soils should always be considered as important criteria in selecting disposal areas or areas to apply residues containing $\mathrm{Cu}$, to minimize soil contamination and the impact on the environment. Residues, effluents and agricultural chemicals applied to the soil can contain a series of chemical species in solution and frequently the electrolytic concentration will be greater than that found in the soil solution, and can cause decrease in $\mathrm{Cu}$ adsorption, in quantitative terms, without affecting the retention force and spontaneity of the reaction of this element with the soil. According to the thermodynamic parameters, $\mathrm{Cu}$ was adsorbed by the soils by energetically favorable and spontaneous reactions throughout the concentration and $\mathrm{pH}$ ranges studied. The investigation of $\mathrm{Cu}$ adsorption was reflected by the values in the variation in the free energy $(\Delta G)$, whose negative sign indicated the exergonic nature of the reaction, with energy release for 
conversion of the less stable forms of $\mathrm{Cu}$ in solution into adsorbed forms with greater stability. With the increase in the $\mathrm{pH}$, the $\Delta \mathrm{G}$ became more negative as a result of the increase in the driving force for the adsorption reaction to take place, especially in the $4-5 \mathrm{pH}$ range. The spontaneity of the reaction was confirmed by the separation coefficient values $\left(\mathrm{K}_{\mathrm{R}}\right)$, which together with the $\Delta \mathrm{G}$ results, were important indications that weathered soils supply important surfaces for $\mathrm{Cu}$ immobilization, especially with the more expressive action of organic matter.

\section{Acknowledgment}

We are grateful to Fundação de Amparo à Pesquisa do Estado de São Paulo (FAPESP) for financial support (process n. 04/00445-3).

\section{References}

1. Kabata-Pendias, A.; Pendias, H.; Trace Elements in Soils and Plants, CRC Press: Boca Raton, 1984.

2. Scheinberg, H. In Metals and Their Compounds in the Environment: Occurrence, Analysis and Biological Relevance; Merian, E., ed.; VCH: Weinheim, 1991, ch. II-9.

3. Yruela, I.; Braz. J. Plant Physiology 2005, 17, 145.

4. Sparks, D. L. In Soil Physical Chemistry; Sparks, D. L., ed.; CRC Press: New York, 1999, ch. 4.

5. Ford, R. G.; Scheinost, A. C.; Sparks, D. L.; Adv. Agron. 2001, $74,41$.

6. Barrow, N.J.; Reactions with Variable-Charge Soils, Martinus Nijhoff Publishers: Dordrecth, 1987.

7. McBride, M. B.; Blasiak, J. J.; Soil Sci. Soc. Am. J. 1979, 43, 866.

8. Cavallaro, N.; McBride, M. B.; Soil Sci. Soc. Am. J. 1980, 44, 729.

9. Harter, R. D.; Soil Sci. Soc. Am. J. 1983, 47, 47.

10. Jeffery, J. J.; Uren, N. C.; Aust. J. Soil Res. 1983, 21, 479.

11. Msaky, J. J.; Calvet, R.; Soil Sci. 1990, 150, 513.

12. Harter, R. D.; Naidu, R.; Adv. Agron. 1995, 55, 219.

13. Petruzzelli, G.; Guidi, G.; Lubrano, L.; Water, Air, Soil Pollut. 1978, 9, 263.

14. McLaren, R. G.; Swift, R. S.; Williams, J. G.; J. Soil Sci. 1981, $32,247$.

15. Alva, A. K.; Huang, B.; Paramasivam, S.; Soil Sci. Soc. Am. J. 2000, 64,955

16. Mesquita, M. E.; Carranca, C.; Silva, J. M. V.; Gusmão, R.; Agrochimica 2004, 48, 222.

17. Casagrande, J. C.; Jordão, C. B.; Alleoni, L. R. F.; Camargo, O. A.; Sci. Agric. 2004, 61, 196.

18. Kinniburg, D. G.; Jackson, M. L.; Syers, J. K.; Soil Sci. Soc. Am. J. 1976, 40, 796 .
19. Benjamin, M. M.; Leckie, J. O.; J. Colloid Interf. Sci. 1981, 79 , 209.

20. Rodda, D. P.; Johnson, B. B.; Wells, J. D.; J. Colloid Interf. Sci. 1996, 184, 365

21. Koppelman, M.H.; Dillard, J.G.; Clays Clay Miner. 1977, 25, 457.

22. Wu, J.; Laird, D. A.; Thompson, M. L.; J. Environ. Qual. 1999, $28,334$.

23. Doula, M.; Ioannou, A.; Dimirkou, A.; Adsorption 2000, 6, 325.

24. Silveira, M. L. A.; Alleoni, L. R. F.; Braz. Arch. Biol. Technol. 2003, 46, 529.

25. Arias, M.; Pérez-Novo, C.; López, E.; Soto, B.; Geoderma 2006, 133,151

26. Yu, S.; He, Z. L.; Huang, C. Y.; Chen, G. C.; Calvert, D. V.; Biogeochemistry 2005, 75, 1.

27. Barrow, N. J.; Bowden, J. W.; Posner, A. M.; Quirk, J. P.; Aust. J. Soil Res. 1981, $19,309$.

28. Hinz, C.; Geoderma 2001, 99, 225.

29. Morera, M. T.; Echeverría, J. C.; Mazkiarán, C.; Garrido, J. J.; Environ. Pollut. 2001, 113, 135.

30. Sodré, F. F.; Lenzi, E.; Costa, A. C. S.; Quim. Nova 2001, 24, 324.

31. Nascimento, C. W. A.; Fontes, R. L. F.; Rev. Bras. Cienc. Solo 2004, 28, 965.

32. Airoldi, C.; Critter, S. A. M.; Clays Clay Miner. 1997, 45, 125 .

33. Silveira, M. L. A.; Alleoni, L. R. F.; Casagrande, J. C.; Camargo, O. A.; Sci. Agric. 1999, 56, 1117

34. Dias, N. M. P.; Alleoni, L. R. F.; Casagrande, J. C.; Camargo, O. A.; Ciência Rural 2003, 33, 829.

35. Soares, M. R.; Alleoni, L. R. F.; Casagrande, J. C.; Quim. Nova 2005, 28, 1014.

36. James, R. O.; Healy, T. W.; J. Colloid Interf. Sci. 1972, 40, 65.

37. Angove, M. J.; Wells, J. D.; Johnson, B. B.; J. Colloid Interf. Sci. 1999, 211, 281.

38. Trivedi, P.; Axe, L.; Environ. Sci. Technol. 2000, 34, 2214.

39. Trivedi, P.; Dyer, J. A.; Sparks, D. L.; Pandya, K.; J. Colloid Interf. Sci. 2004, 270, 77.

40. Soil Survey Staff; Soil Taxonomy: a Basic System of Soil Classification for Making and Interpreting Soil Surveys, $2^{\text {nd }}$ ed., Government Printing Office: Washington, 1999.

41. Camargo, O. A.; Moniz, A. C.; Jorge, J. A.; Valadares, J. M. A. S.; Métodos de Análise Química, Mineralógica e Física de Solos, Instituto Agronômico de Campinas, IAC: Campinas, 1986.

42. Raij, B. van; Andrade, J. C.; Cantarella, H.; Quaggio, J. A.; Análise Química para Avaliação da Fertilidade de Solos Tropicais, IAC: Campinas, 2001

43. Mekaru, T.; Uehara, G.; Soil Sci. Soc. Am. Pro. 1972, 36, 296.

44. Weber, O. L. S.; Chitolina, J. C.; Camargo, O. A.; Alleoni, L. R. F.; Rev. Bras. Cienc. Solo 2005, 29, 867. 
45. Alleoni, L. R. F.; Camargo, O. A.; Rev. Bras. Cienc. Solo 1994, $18,175$.

46. Gee, G. W.; Or, D. In Methods of Soil Analysis: Physical Methods; Dane, J. H.; Toop, G. C., eds.; S.S.S.A.: New York, 2002, ch. 4.

47. Feller, C.; Schouller, E.; Thomas, F.; Rouiller, J.; Herbillon, A. J.; Soil Sci. 1992, 153, 293.

48. Tan, K. H.; Hajek, B. F.; Barshad, I. In Methods of Soil Analysis; Klute, A., ed.; S.S.S.A.: Madison, 1986, ch. 7.

49. Goldberg, S.; Forster, H. S.; Heick, E. L.; Soil Sci. Soc. Am. J. 1993, 57, 704 .

50. Angove, M. J.; Johnson, B. B.; Wells, J. D.; J. Colloid Interf. Sci. 1998, 204, 93.

51. Suarez, D.L. In Soil Physical Chemistry; Sparks, D. L., ed.; CRC Press: Boca Raton, 1999, ch. 3.

52. Rawat, J. P.; Umar Iraqi, S. M.; Singh, R. P.; Colloid. Surface. A 1996, 117, 183.

53. Aksu, Z.; Process Biochem. 2002, 38, 89.

54. Ho, Y. S.; Huang, C. T.; Huang, H. W.; Process Biochem. 2002, $37,1421$.

55. Singh, T. S.; Pant, K. K.; Sep. Purif. Technol. 2004, 36, 139.

56. Petruzzelli, G.; Guidi, G.; Lubrano, L.; Commun. Soil Sci. Plan. 1985, 16, 971 .

57. Jordão, C. P.; Alves, N. M.; Pereira, J. L.; Bellato, C. R.; Quim. Nova 2000, 23.

58. Giles, C. H.; Smith, D.; Huitson, A.; J. Colloid Interf. Sci. 1974, 47,755 .
59. Sposito, S.; The Chemistry of Soils, Oxford: New York, 1989.

60. Silveira, M. L. A.; Alleoni, L. R. F.; Casagrande, J. C.; Camargo, O. A.; Commun. Soil Sci. Plan. 2002, 33, 3581.

61. McLaren, R. G.; Crawford, D. V. S.; J. Soil Sci. 1973, 24, 443.

62. Temminghoff, E. J. M.; Van Der Zee, S. E. A. T. M.; Keizer, M. G.; J. Soil Sci. 1994, 158, 398 .

63. Alva, A. K.; Baugh, T. J.; Sajwan, K. S.; Paramasivam, S. J; Environ. Sci. Health B 2004, 39, 903.

64. Spark, K. M.; Johnson, B. B.; Wells, J. D.; Eur. J. Soil Sci. 1995, $46,621$.

65. Zhang, X. N.; Zhao, A. Z. In Chemistry of Variable Charge Soils; Yu, T. R., ed.; Oxford University Press: New York, 1997, ch. 2.

66. Stahl, R. S.; James, B. R.; Soil Sci. Soc. Am. J. 1991, 55, 1291.

67. Stevenson, F. J.; Humus Chemistry: Genesis, Composition, Reactions, John Wiley \& Sons: New York, 1994.

68. Criscenti, L. J.; Sverjensky, D. A.; Am. J. Sci. 1999, 299, 828.

69. Mesquita, M. E.; Vieira e Silva, J. M.; Geoderma 2002, 106, 219.

70. Bowden, J. W.; Posner, A. M.; Quirk, J. P.; Aust. J. Soil Res. 1977, 15, 121.

Received: October 24, 2007 Web Release Date: May 30, 2008

FAPESP helped in meeting the publication costs of this article. 